This paper is a post-print of an article published in Social Dynamics 29:1 (2003): 27-48. The definitive version is available at: http://www.africanstudies.uct.ac.za/downloads/29_1 farquharson.zip

\title{
Transforming the Springboks: Re-imagining the South African Nation through Sport
}

\section{Karen Farquharson and Timothy Marjoribanks ${ }^{1}$}

\begin{abstract}
Nation-building occurs not only through the creation of formal institutions, but also through struggles in cultural and symbolic contexts. In apartheid South Africa, the rugby union Springboks both symbolised and institutionalised a racially based form of 'bounded citizenship'. In post-apartheid South Africa, the Springboks have emerged as a contested and significant site in the attempt to build a non-racial nation through reconciliation. To explore these contests, we undertook a qualitative thematic analysis of newspaper discourses around the Springboks, reconciliation and nation-building in the contexts of the 1995 and 1999 Rugby World Cups. Our research suggests, first, that the Springboks have been re-imagined in newspaper discourses as a symbol of the non-racial nation-building process in South Africa, especially in 'media events' such as the World Cup. Second, we find that there are significant limitations in translating this symbolism into institutionalised practice, as exemplified by newspaper debates over the place of 'merit' in international team selection processes. We conclude that the media framing of the role of the Springboks in nation-building indicates that unless the re-imagination of the Springboks is accompanied by a transformation in who is selected to represent the team, and symbolically the nation, the Springboks' contribution to South African nation-building will be over.
\end{abstract}

\section{Transforming the Springboks: Re-imagining the South African Nation through Sport}

Some nine years after the first all-race elections in 1994, there continues to be significant debate about how South Africa should re-invent itself as a nonracial nation. One area in which the transformation of the South African nation has been the subject of fierce contestation is the sporting arena, notably in debates around the relationship between rugby union and the postapartheid nation-building process. In particular, the role of the South African national team, the Springboks, in nation-building has been the subject of discussion and analysis.

The victory of the Springboks in the 1995 Rugby World Cup was considered by many media commentators, politicians and sporting identities at the time to be symbolic of both the end of apartheid and of the way forward to reconciliation in South Africa. Perhaps the defining moment for this interpretation was the image of political and spiritual leaders President Nelson Mandela and Archbishop Desmond Tutu wearing the Springbok jersey. Since that occasion, the relationship between the Springboks and the process of nation-building has been the subject of a number of studies, with a variety of conclusions being reached. Rees suggested, for example, that 'the recent victory of South Africa in the Rugby World Cup (June 1995) has great symbolic value for the country, representing an irrevocable break with the apartheid past and a positive vision of the future' (Rees, 1996: 22). By contrast, Steenveld and Strelitz conclude that the tournament 'represented no more than a utopian moment', which 'in no way laid the foundation - as the media and the government politicians would have us believe - for the creation of a collective self- 
identity' (Steenveld and Strelitz, 1998: 625). These contrasting views represent two sides of an ongoing debate around the role of the Springboks in nation-building.

In 1999, South Africa participated in another Rugby World Cup, this time in Europe. In the context of these two international sporting events, we examine the relationship between the Springboks and nation-building in the post-apartheid period, as framed by key English language newspapers. We argue, first, that the Springboks continue to be mobilised as a symbol of the nonracial nation-building process in post-apartheid South Africa, in particular at times of major sporting events such as the Rugby World Cup. Second, we argue that there are significant limitations in translating this symbolism into institutionalised practice, and that this is exemplified by newspaper debates over the place of 'merit' in international team selection processes. We conclude that the conflicts associated with institutionalising non-racialism in elite rugby ultimately pose significant problems for the symbolic role of the Springboks in the nationbuilding process.

\section{Nation-building, Sport and the Media}

\section{Nation-building as process}

Analyses of nation-building must take into account Benedict Anderson's proposition that the nation 'is an imagined community - and imagined as both inherently limited and sovereign' (Anderson, 1991: 6). In using the concept of imagination, Anderson suggests that in a nation of any size, while most members will not know each other, they are brought together by 'the image of their communion' (ibid). The concept of imagined communities also carries with it the idea that nations can be re-imagined and thereby transformed.

The question then arises of who is involved in the nation-building process. Critical engagements with Anderson's concept of imagined community, and Anderson's own reformulations of his original concept, indicate that nation-building is not necessarily a benign or unifying process involving all members of a society, but may well be the result of the imposition of coercive power and of exclusion by political or economic elites (ibid; Magubane, 1996; Marx, 1997, 1998; Seidman, 1999). As Anthony Marx has shown in relation to South Africa, analysis of the history and processes of racial domination is central to gaining an understanding of the form of nation that existed in the twentieth century. Central to the imagination of the apartheid South African nation was the exclusion of blacks from its citizenry. Apartheid South African 'bounded citizenship', then, created a nation that bound whites together by its omission of other races (Marx, 1997, 1998). A new South Africa must change the bounds of its citizenry. Such approaches suggest that we need to analyse which groups possess the resources to enable them to participate in nation-building, and thereby become part of the 'bounded citizenry'.

Nation-building is an ongoing and contested process, occurring through the creation of formal political, economic and social institutions and also through struggles in cultural and symbolic contexts (Greenfeld, 1992; Goldberg, 1993; Christopher, 2001). Such struggles across all sectors of society are important in relation to nation-building, not only because of who is ultimately defined as belonging to a nation but also in terms of defining who is excluded. These processes of inclusion and exclusion can occur across a number of axes, with race often being a crucial demarcation (Anthias and Yuval-Davis, 1992; Goldberg, 1993; Greenstein, 1993; Omi and Winant, 1994; Frederickson, 1995; Magubane, 1996; Farquharson, 1999). Even in the first post-apartheid elections in South Africa, in which non-racialism was central to the political manifestos of the major political parties, 'race and ethnicity were enmeshed with the definition and encouragement of national unity' (Marx, 1998: 215). The very act of rejecting race as a basis for social relations brings race into the mix of nation-building. However, race operates in specific contexts, and in this particular instance we turn to representations of sport in the media as a means of analysing the process of nation-building, including its racial dynamics, in post-apartheid South Africa. 


\section{Nation-building, sport and media}

When race does operate as a basis for nation-building, it may do so directly through legislation as in the apartheid era, but it may also operate indirectly through social or cultural activities and symbols. In this context, sport has been a significant marker of both race and nation in various contexts (Jarvie, 1985, 1991; Hobsbawm, 1990; Pope, 1993; Jarvie and Walker, 1994).

Research on the relationship between sport and nation-building suggests that the symbolic and institutional manifestations of the relationship are context specific (Jarvie and Walker, 1994; for the South African context, see Jarvie, 1985; 1991; Roberts, 1989; Grundlingh, Odendaal and Spies, 1995; Booth, 1996; 1998; Nauright, 1997; Keech and Houlihan, 1999). Central to this context is the media. Crucially for our purposes, there is an increasingly close relationship between media, the nation and sport, with the media playing a key role in "producing, reproducing and amplifying' discourses around sport and the nation (Blain, Boyle and O'Donnell, 1993: 15).

Indeed, for many people, sport is consumed through the media rather than through direct participation or attendance at games. As a result, the media are a potentially powerful site for the framing of discourses around the relationship between sport and nation-building. The notion of framing is used here to suggest that through decisions about which issues to report, and about how to report those issues, the media present particular versions of 'social reality' (Schudson, 1995; Street, 2001). While these frames are not the only versions of 'reality' available, the wide circulation of media forms gives the views presented in the media a significant potential to 'reflect and influence the formation and expression of cultural, political and social life' (Garrett and Bell, 1998: 4; see also van Dijk, 1997). This potential is heightened further in the case of high profile sporting 'media events' which 'spotlight some central value or some aspect of collective memory' (Dyan and Katz, 1992, quoted in Steenveld and Strelitz, 1998: 616). The Rugby World Cup, for example, is not only a sporting event involving teams from around the world, but is also an opportunity for host nations to present an image of themselves to a global audience, in particular through the exposure offered by different media forms.

\section{Nation-building in the New South Africa: Reconciliation, Race, Nation and Sport}

The process of unmaking apartheid and of imagining a new South Africa has been full of contradictions whereby, for example, political enfranchisement is accompanied by growing inequalities of wealth (Goodman, 1999; Williams and Taylor, 2000; Christopher, 2001; Nattrass and Seekings, 2001). Despite the emergence of such contradictions, the political leadership has remained committed to reconciliation as being central to the reconstitution of the South African nation. Reconciliation confronts the challenge of 'faithfully record[ing] the pain of the past so that a unified nation can call upon that past as a galvanising force in the large tasks of reconstruction' (Asmal, Asmal and Suresh Roberts, 1997: 6).

Captured in institutional practices such as the Truth and Reconciliation Commission, reconciliation is also embodied in the language of non-racialism and the rainbow nation. Nonracialism had been the ideology of the ANC leadership long before the end of apartheid, and in the 1990s also became the ideology of the former party of apartheid, the National Party. According to historian Julie Frederikse, the essence of non-racialism is 'a democracy in which people are not differentiated according to racial criteria, but enjoy rights as equal citizens in one united country' (Frederikse, 1990: 3-4). The non-racial ideal would be a nation where race is not a factor; a nation where everyone is equal.

In contrast to non-racialism, the rainbow nation ideology reflects a multi-racial ideal: a nation where different ethnic groups can live harmoniously alongside each other, like the colours 
of a rainbow. Although the racial ideologies of non-racialism and rainbow nation are both opposed to apartheid, they reflect different visions for post-apartheid South Africa.

While the ideology of non-racialism is now dominant in South Africa, at least at the level of official discourse, it is important to recognise that non-racialism, rainbow nation and reconciliation are contested terms. In particular, contests have emerged over the extent to which non-racialism can allow for affirmative action to compensate for past injustices, and to what extent it requires a form of colour-blindness in which race is immediately ruled to be irrelevant and not the proper subject of political action. This contest has had a profound impact on attempts to build the new South African nation (Adam, 1997; Croucher, 1998; Farquharson, 1999).

The question of how these concepts of reconciliation and non-racialism are to be transformed into institutional practice is, of course, vital. In this regard, the cultural and symbolic context is crucial, and in analysing the processes of nation-building and reconciliation, sport emerges as a crucial arena of transformation. During apartheid, South African sport, including rugby, was racially segregated. This contributed to a set of circumstances in which particular sports were identified with different race groups, in terms of participation, administration and consumption (Jarvie, 1985, 1991; Grundlingh, Odendaal and Spies, 1995; Nauright, 1997; Booth, 1998).

Racial categorisation was also important in relation to the meaning of symbols attached to specific teams and sports. White South African sports teams competed during apartheid under the Springbok emblem, which came to symbolise a racially based form of 'bounded citizenship'. This racialization of rugby, and of the symbolism of the sport, was heightened by the role of the Afrikaner-dominated administration of rugby, which understood the goal of Afrikaner dominance in society to be intimately linked to control over sport (Dubow, 1995; Grundlingh, Odendaal and Spies, 1995; Magubane, 1996; Nauright, 1997; Booth, 1998). In particular, the international success of the Springbok rugby union team was appropriated by the administration as a symbol of supposed Afrikaner superiority.

At the same time, rugby and the Springbok also came to be used as a means of mobilisation by opponents of the apartheid regime internally and externally, thereby providing a potential basis for an alternative relationship between sport and the South African nation (Booth, 1998; Keech and Houlihan, 1999). Once it became clear that apartheid would officially end, questions began to emerge as to what a post-apartheid South Africa would look like. Within this debate, the question of the role of sport and of the symbols associated with sport in the new South Africa became important. Perhaps most powerfully, this question has arisen in the context of the rugby union Springboks.

\section{The 1995 and 1999 Rugby World Cups: A Case Study}

We have argued that the media is a critical site for the consumption of sport, and also for the construction of discourses around the relationship between sport and nation. These media roles are heightened in major international sporting competitions, to the extent that such competitions can be referred to as media events. Taking these arguments as our starting point, we conducted a qualitative thematic analysis of print media discourses around rugby, reconciliation and nationbuilding in the contexts of the 1995 and the 1999 Rugby World Cups. In the case of the 1999 Rugby World Cup, much of the debate occurred prior to the event, when team selection processes were hotly contested.

The newspapers comprising our sample are the newspapers owned as of 2001 by Independent Newspapers, a wholly owned subsidiary of Independent News and Media (South Africa) Group. Independent Newspapers promotes itself as the leading newspaper group in South Africa, with fourteen daily and weekly newspapers in the country's three major metropolitan areas. Among these titles are Cape Times, Cape Argus, Star, the Mercury, the Sunday 
Independent, and the Daily News. Independent Newspapers has sales across all its titles of 2.8 million copies each week in Gauteng, KwaZulu Natal and the Western Cape (Jacobs, 1999; Independent, On-Line 2001). While not constituting all South African newspapers, the reach of the increasingly dominant Independent Newspapers makes them a critical site for analysis of the representation of nation and sport.

The data for this paper consists of 220 items, including primarily articles, but also editorials, opinion pieces, and letters to the editor. Items were collected through a combination of hand and worldwide web searches. The items appeared between January 1995 and December 1999, and referred explicitly to some aspect of the Springbok-nation-building relationship in the context of the 1995 and 1999 Rugby World Cups. Each item was treated as a separate piece of data, and was coded for key words and ideas around nation-building, providing the foundation for a thematic analysis.

The 1995 Rugby World Cup marked the re-entry of the Springboks to the international arena. It was also the first major international sporting event hosted in post-apartheid South Africa and the Springboks rose to the occasion, winning all their matches. The entire South African nation celebrated when the Boks won the World Cup. The situation was different for the 1999 World Cup in Europe. Prior to the 1999 tournament the Springboks had been the subject of

a much-reported controversy surrounding the team's lack of black players. This debate centred on the selection criteria and shaped the coverage of the 1999 World Cup. The Springboks finished third in the tournament, a relative failure for them.

Three key themes emerged from our analysis of the newspaper items. The first theme was that the Springboks have a positive role to play in the symbolic process of nation-building in postapartheid South Africa. This was a major theme of the 1995 Rugby World Cup newspaper coverage of the Springbok, and it re-emerged in 1999.

The second theme was that the process of non-racial nation-building would occur through reconciliation, and that the Springboks in the context of the Rugby World Cup are an important site for such reconciliation. This theme was particularly prominent in debates around the time of the 1995 World Cup about retaining the Springbok as the emblem for the national rugby team.

By 1999 the decision to retain the Springbok for the rugby team had been made, and the theme of reconciliation was no longer present in newspaper coverage. In its place was the third theme, which centred on the shift from symbolic to institutionalised non-racial nation-building in the make-up of the rugby team. In particular, newspaper coverage surrounding the 1999 Rugby World Cup focused on debates between merit and quotas in the selection and desegregation of the Springbok squad. Discourses around merit and quotas suggest that it has proved very difficult for South African rugby to move from nation-building at the symbolic level to nation-building at the material level, where black South Africans are chosen to represent their country.

The interaction of these three key themes suggests that nation-building through sport is a complex and contradictory process, in which the place of the Springboks as a symbol of nationbuilding is being threatened by the failure to institutionalise non-racial practices in rugby. The discourses around the Springbok and nation-building shifted dramatically between 1995 and 1999, as the South African nation worked to re-imagine and transform itself.

\section{Theme 1: Nation-building}

What is immediately striking about newspaper coverage of both the 1995 and 1999 Rugby World Cups is the assumption that there is, and should be, a positive link between the Springboks and nation-building. This theme suggests that the Springboks, despite having been a symbol of the divisions of apartheid, could, and perhaps have, become a symbol of inclusiveness in a new South Africa.

In the context of the 1995 Rugby World Cup, the Springboks were presented in the media 
as a way to bring the nation together. President Mandela was quoted, for example, as claiming that:

'Even before the whistle was blown for the kick-off at Newlands [in Cape Town], South Africa had already won in the hearts of the nation. When the final whistle blew a month later, the foundations for reconciliation and nation-building had been truly strengthened. Our nation united behind one team and that team did the nation proud.' (Cape Times, 1995d: 1)

According to newspaper coverage of the 1995 World Cup, that black South Africans, many of whom had supported South Africa's opponents in past rugby tours as a way of protesting apartheid, came together with white South Africans in support of the Springboks was a significant step forward in creating a new South African nation. If blacks could support the Springboks, there was hope for the building of a non-racial South African nation.

Others echoed Mandela's view that the Springboks could provide an important vehicle for South Africans of all races to bond as a nation: The final whistle of the Rugby World Cup on Saturday which established the Springboks as the rugby champions, unleashed a night of celebration that united South Africans across the country... 'Forget about the old South Africa', said Mr Morena Kgosana of Soweto. 'This is the new South Africa. We are united now.' (Cape Times, 1995b: 3)

[T] he Springboks played like men inspired [in the World Cup final]. When all seemed lost they saved the day by tackling like tigers. The exercised a newfound discipline even when provoked. Their final victory, without losing a single match throughout the tournament, has lifted the nation's spirits and achieved a national unity that can be compared with Nelson Mandela's election as President. (Cape Times, 1995a: 8)

Given the historic association of the Springboks with apartheid, and with its particular form of imagined community and bounded citizenry, these claims about the positive relationship between nation-building and the Springboks amounted to a major transformation in perception.

Four years later, in the newspaper coverage of the 1999 Rugby World Cup, the relationship between the Springboks and nation-building was again purposefully asserted. The Chief Executive of the South African Rugby Football Union (Sarfu), Rian Oberholzer, said at the time: 'We decided at a meeting a year ago that we wanted the World Cup to be used as a vehicle for nation-building, something that was done very successfully in 1995' (Rich, 1999c). As part of this nation-building process, Mandela's voice was used in advertisements promoting the 1999 World Cup, while Tutu and then newlyelected South African President Thabo Mbeki appeared in public wearing Springbok jerseys, mirroring the actions of Tutu and Mandela in 1995 (Rich, 1999c). With the announcement that the thirty-player 1999 Rugby World Cup squad contained four black players, journalist Barry Glasspool reported the Minister of Sport Ngconde Balfour as saying: 'This is a team representative of all groupings in this country and deserves our full support' (Glasspool, 1999). Dan Qeqe, represented in the press as 'the elder statesman of black rugby', was quoted as emphasising 'that the current team of Rainbow Warriors would be representing others like himself whose passion for playing international rugby had been prevented by apartheid's separatist policies' (ibid). The ANC also released a statement to the effect that:

The people of South Africa are wholly behind [coach] Nick Mallett, [captain] Joost van der Westhuizen and the rest of the squad. They carry with them the dreams and aspirations of the whole country in the glorious pursuit of further international honours. (Saturday Star, 1999, emphasis added)

Following the World Cup, President Mbeki reaffirmed these sentiments, indicating that 'sport [including rugby] had contributed greatly to nation-building' (Pretorius, 1999). Through the detailed and positive framing of such statements, the print media in 1999 reaffirmed the positive symbolic link between the Springboks and nation-building made so clear in 1995.

The shift from the Springboks as a symbol of apartheid to symbol of the new non-racial South Africa represents an attempt to re-imagine the Springboks as a team for all South Africans. In 1995, this symbolic shift was represented in the media as being a significant accomplishment in itself. By 1999, however, concerns had begun to emerge that the Springboks were not fulfilling 
their role in institutionalising nation-building. In particular, concerns were expressed about the lack of the contribution of rugby to the specific processes of building a non-racial nation through reconciliation.

\section{Theme 2: Reconciliation}

At the 1995 Rugby World Cup, the relationship between rugby, reconciliation and nationbuilding was evident in newspaper debates over whether to retain the Springbok as the emblem of the national team. In the early $1990 \mathrm{~s}$, moves had begun to desegregate the national sports teams and to change their symbol from the Springbok as part of the process of creating a non-racial South African nation. Indeed, the 1995 Rugby World Cup was to be the last time that the Springbok emblem would be used to represent a South African sports team. During the 1995 World Cup, however, vigorous debates regarding the Springbok emblem and its role in reconciliation emerged in the press. Calls for both its removal and retention were made by political and other leaders, journalists and letter writers, with each side arguing that the Bok should be either retained or removed in the name of reconciliation.

The following quote, from the front page of the Cape Times, was typical of the kind of argument made by those who sought the Springbok's retention:

Mr. Mandela said the time had arrived for all South Africans to support the Springbok emblem as this would help cement the spirit of unity and reconciliation forged by the team's World Cup triumph. (Cape Times, 1995c: 1, emphasis added)

A letter writer commented that:

Apartheid is dead, so let the Springbok live - not only in the wilds, but as the proud emblem of a proud country. It is not interested in politics; it promotes a strong and multi-faceted image and, above all, is a survivor! (Cridland, 1996: 4)

Those supporting the Springbok argued further that it would help to bring the Afrikaner community, dedicated Springbok rugby supporters, into the new South Africa. Retaining the Springbok was framed in the press as reconciliation through compromise, bringing Afrikaners into the fold by allowing them to keep their symbol.

There were, however, many who passionately argued that the Springbok should be dropped for all South African teams, including rugby:

The Bok emblem must be scrapped. It is part and parcel of the old regime

which divided [South Africa]. If [South Africa] is to move towards unity then

the codes of sport must not be divided but have one national emblem.

(Philander, 1996: 8, emphasis added)

Like those who supported the Springbok's retention for rugby, those who wanted its complete removal argued that it must be dropped in the name of unity and reconciliation. For many, the Springbok was indelibly associated with apartheid and its racism.

Crucial to these debates was the context of the 1995 Rugby World Cup. The shape of the post-apartheid era was still not certain, and there was an air of great hope that things could and would change for the better for all South Africans. The Springbok was one of many potential sites for reconciliation and transformation. Its retention, as the discussion above indicates, was hotly debated. The ultimate decision to retain the Springbok, despite recommendations after the 1995 World Cup from the National Sports Council that it should be scrapped, was influenced crucially by Nelson Mandela, Desmond Tutu and Steve Tshwete, the Minister for Sport (Grundlingh, Odendaal and Spies, 1995; Booth, 1998). The most powerful symbolic manifestation of this support came when Mandela and Tutu both wore the Springbok jersey at the 1995 World Cup in public displays of reconciliation and forgiveness. The influence of Mandela and Tutu in the Springbok's retention, and its relationship to reconciliation, is exemplified in the following letter:

If the expressed wish of the two best-known and respected South Africans is ignored in an act of 
calculated non-reconciliation and the Springbok emblem is culled from the rugby jerseys, then the fabricator of the RSA rugby jerseys should adopt the Springbok as his company logo and advertise the company on the jersey on the breast opposite the proteas. (Davies, 1996: 6, emphasis added)

This writer invokes the importance of the leadership of Mandela and Tutu and argues that dropping the Springbok would be an act of 'non-reconciliation.'

The data on the Springbok show that reconciliation is linked to the process of re-imagining the bounds of South African citizenry and redefining who can change those bounds. The appropriation and transformation of the Springbok by the new political leadership on behalf of all South Africans can be interpreted as a means of re-drawing the boundaries of South African citizenship through reconciliation. As journalist David Miller commented:

For Nelson Mandela, it [wearing the jersey] was a touch of genius. To take hold of the very colours of your historic enemy, of your cultural, social and political oppressor, and to raise them aloft as a symbol of brotherhood, was more powerful than a million words.

With a mere green and yellow cloth on his back, instead of resorting to guns and bombs, this unique statesman's gesture has overturned a former hated bastille of racist privilege and created, instead, a talismanic club of equality. (Miller, 1995: 6)

In a similar way, a Cape Times editorial commented:

Many who were swept along by the success of the South Africa rugby team during the World Cup also appeared to undergo a change of heart towards the Springbok symbol, in part perhaps because of the way leaders like Mr Mandela displayed such warm and open identification with the national team, Springbok emblem and all. Indeed, by the end of the tournament the Springbok symbol, proudly worn by the President before millions of television viewers world-wide, seemed to become part of a new patriotic fervour sweeping the country. As Archbishop Tutu remarked last week, 'We have been able to turn symbols around in this country.' (Cape Times, 1996: 8)

While dissenting voices were evident in the newspaper coverage of the Springbok symbol, most coverage in 1995 argued that keeping it would contribute to building a non-racial nation through reconciliation.

It was soon recognised, however, that more concrete steps would need to be taken to ensure that rugby was an active player in the process of reconciliation. Louis Luyt, then President of Sarfu, was reported in 1997 as having promised to President Mandela that 'the team to defend the World Cup in Wales in two years time would be "rainbow nation" in character' (Granger, 1997). In the period prior to the 1999 World Cup a number of steps (discussed below) were taken by Sarfu in an attempt to include more black players in rugby.

Emerging out of these initiatives, symbolic reconciliation was no longer an overt theme in the newspaper coverage of the lead-up to the 1999 Rugby World Cup and of the event itself. The media focus was now on the institutional changes required for rugby to transform itself, including, in particular, changes in the racial make-up of the Springbok team. Symbolic nonracialism is vital, but the 1999 World Cup media debate centred on the institutionalisation of nonracialism.

\section{Theme 3: Symbolic vs. Institutional Nation-building}

Despite the promises of senior rugby officials such as Luyt that rugby was transforming itself, in the lead up to the 1999 World Cup, Steve Tshwete was reported as saying 'that the lack of change in the "physical chemistry" of national teams was creating disillusionment in the black community' (Rantao, 1998), while a Cape Times reporter wrote that: 'There have been rumblings in the black rugby community for some time that while the "One Nation" pledge of 1995 might have been born in good faith, it has since become a problem child that is in urgent need of correction' (Greenaway, 1999a). These concerns were to be highlighted further in media debates around selection policies for the 1999 Springboks, and their importance for non-racial nationbuilding. Much of this debate occurred in the build-up to the 1999 Rugby World Cup.

One way in which Sarfu has sought to ensure that rugby moves from symbolic change to 
transform itself institutionally has been by introducing measures to support black players, including the creation of a category of development players, and through quotas (Del Carme, 1999; Greenaway, 1999b). These attempts to transform rugby at all levels of the game have met with both widespread support and condemnation. As has been the case in other areas of nationbuilding in South Africa (Adam, 1997; Farquharson, 1999), those in favour of these attempts at transformation praise them as necessary forms of affirmative action in a context in which the practices of apartheid will not be undone by relying on goodwill alone. Opponents argue that, especially at the elite level, team selection must be based on colour-blind individual merit alone.

In the case of the Springboks, media debates around affirmative action and merit arose in coverage of the selection of individual players. In the lead up to the 1999 World Cup, when the Springboks played a series of 'warm up' test matches, Sarfu's Chief Executive Oberholzer spoke out strongly on the need for rugby to be aware of the realities of transformation, and that all aspects of the game, including selection practices, needed to reflect transformation in practice. Prior to the test match versus Wales, it was revealed that coach Nick Mallett intended to omit a black player, Breyton Paulse, who at the time was one of only two black players in the squad of twenty-six players. Despite the acknowledgment that Paulse was in good form at the time, attempts to justify his potential omission from the team were raised in terms of the 'need to win' at the elite level, where it was the coach's duty to select the 'best possible team'. Mallett himself came forward and argued that selection at the elite level of rugby should be based on merit:

I will not be pushed around on this issue. I feel very strongly about it. There is no way I will ever take part in anything that can be construed as window dressing. [He continued:] The changes need to be made at grassroots, through the age groups and at provincial level. When you get to international level, you have to be the best there is. That is what international sport is about. (Ntabazalila, 1999)

Commenting on the reaction of elite players to Oberholzer's reported argument that the Springboks needed to transform themselves, 'and that it would no longer be acceptable for white players to be pushed ahead of realistic black contenders', journalist Gavin Rich wrote that:

Most of the [Springbok] players are believed to have given Oberholzer's insistence that they must adapt to the realities of South African life a lukewarm reception. This should be regarded as understandable. A top [white] player like winger Pieter Rossouw, mindful of the fact that most top black players are wings, might be nervous that a move towards affirmative selection could limit his appearances at Test level. (Rich, 1999a)

Here, the attempt to institutionalise non-racialism is reduced to a personalised contest between individual players, and removed from the broader societal context.

The counter case to this line of argument was put forcefully by a number of journalists, including Gavin Rich himself, who argued that:'[q]uota systems may be an odious concept, but it has become clear that they are an extremely necessary evil in South African rugby' (Rich, 1999b). According to Rich, events since 1995 indicated that it was not possible to rely on the goodwill of rugby officials if the politically required transformation of South African rugby was to occur ( $i b i d)$. Commenting that the consistent lack of opportunities being provided to black players meant that he had lost his 'naïve' belief 'that our fourteen white provincial coaches and their bosses were free of prejudice', Rich went on to argue: 'At a time when rugby desperately needs to widen both its support and resource base to confront the challenges of a changing South Africa, the Boks cannot afford to field an all-white team' (ibid). Similarly, while journalist Max du Preez acknowledged the arguments in favour of merit, he went on to reject them:

If only sport was merely about physical competition between individuals or teams. But it is more about passion, symbolism, nationalism and big, big money.

That is why it is naïve of sports people, administrators and fans to insist on a simplistic 'merit only' policy when it comes to top teams, especially the two predominantly 'white' sports, rugby and cricket. It is simply not realistic in our society today.

When one watches South Africa's national team play an overwhelmingly 'white' country, and there are two or three black players in that team, but our overwhelmingly 'black' country's team is completely 
white, then even the greatest sports fanatic knows deep inside him: whatever the arguments something is wrong here.

[...] I'm afraid the old struggle slogan of the 1980s is still valid: there can be no normal sport in an abnormal society. And normal we still are not. (du Preez, 1999)

In another important contribution to this debate, Rich also employed the technique of personalising the debates around merit and opportunities in the context of Springbok team selection. He wrote:

The fact that not everyone in South African rugby is a racist does not change my perception that a black player has to conquer many negative mindsets to be recognised for his true value. Let's illustrate the point with a question: Would Dave von Hoesslin [a white player], given his inexperience at the top level and the rough edges to his play, have played scrum-half for South Africa were he born black? Breyton Paulse [a black player] would never have played in Dunedin were it not for the pressure from those campaigning for transformation. Some of us were told in Cardiff that he was not going to play, the reason being that Carisbrook was considered a tough place for a young player to play his first big test. When I asked management why they did not use the same criterion with Von Hoesslin, I did not receive an answer. Probably because there is no really satisfactory one. (Rich, 1999d)

Soon after, the Cape Times published an article in which fans watching a Springbok training session were reported as being overwhelmingly in favour of the inclusion of black players. One supporter was reported as saying: 'to sustain the support of the public, he [coach Nick Mallett] must make the Springbok side more representative of the people playing the game', while another supporter claimed: 'I would like to see the team being more representative and I don't accept the excuses they are coming up with' (Abrahams and Ntabazalila, 1999). In the same article, Springbok manager Arthob Petersen was quoted to different effect, arguing: 'At this stage let's not get into a debate about who should play where, but we should go out and select the best side to represent South Africa on Saturday' (ibid). By reporting such perspectives, this particular article captures well the competing claims around institutionalising non-racialism at the elite level.

Whereas those arguing in favour of so-called 'merit-based' team selection claim that standards are all important, especially at the national level, those arguing for quotas suggest that their use is one way of institutionalising non-racialism, and ultimately of furthering the role of rugby in the transformation process. In terms of media framing of these debates, key journalists presented a case arguing that merit alone is insufficient by focusing on comparisons between individual players, and also by locating rugby within the broader transformation process, thereby reaffirming the importance of the sport to building a new South Africa.

A common theme to emerge in the newspaper coverage in the aftermath of the 1999 World Cup was that the relative failure of the Springboks in finishing third meant that members of the rugby community could no longer delude themselves that all was well. Instead, rugby officials would need to address a number of issues, including the role of the Springboks in the transformation of the South African nation. This perspective was well captured in an article by Mike Greenaway, in which he approvingly quoted rugby administrator Dan Qeqe:

'I am very worried about the attitude of whites. I accept that it takes time for attitudes to change, but how much longer must we wait before there is complete acceptance of other citizens of the same country...[W]hites must start realising a lot of people are getting very fed up. Conciliation is all very well, but I am warning you that patience is running out. Whites must change their attitudes NOW!' (Greenaway, 1999a).

These newspaper debates around concepts such as merit and quotas give some indication of the complexities involved in institutionalising non-racialism in the Springboks, until recently such a potent symbol of apartheid. In particular, while some voices represented in the press support team selection for the Springboks on the supposedly neutral basis of merit, other voices indicate the ways in which merit cannot be understood independent of the societal context. At the same time, tensions between social transformation and its impact on individual players are highlighted in the 
press. In this way, newspaper coverage is framing rugby as a key site of transformation, not only symbolically, but also at the level of institutional practice. Statements such as those made by Qeqe, as quoted above, also suggest that unless institutional transformation occurs, for example through selecting more black players for the national rugby union team, even the role of the Springboks as a symbol of a non-racial South Africa will be under threat.

\section{Conclusion: Re-imagining the South African Nation through Sport}

Nations are what their citizens imagine them to be, and nation-building occurs not only through political and economic processes, but also in cultural and symbolic contexts. In this regard, arenas such as sport, and representations of sport and nation in the media, are crucial sites for imagining and re-imagining the nation. Symbols such as the apartheid era Springbok represented exclusion, domination and a racially based 'bounded citizenry'. The adoption of non-racialism by the postapartheid government provides a framework which allows for the attempt to recreate, to reimagine previously divisive symbols such as the Springbok as symbols of a new nation and of reconciliation. This case study of print media framing of the relationship between the Springboks and nation-building has shown that the symbols of the apartheid era are being redefined under the direction of the black political leadership in a contested process, and that the outcomes of these contests are important to the participants. Even though de facto apartheid remains in many areas of everyday life, this symbolic shift marks an important change in perception of the boundaries of citizenship for black and white South Africans.

At the same time, the case of the Springboks, and of rugby more broadly, in South Africa shows the potential limitations of symbols associated with sport in nation-building. While symbolic change was accepted as appropriate in 1995, by 1999 media framing indicated that the failure to institutionalise such change was threatening the symbolic role of the Springboks. Unless the re-imagination of the Springboks is accompanied by a transformation in who is selected to represent the team, and symbolically the nation, the Springboks' contribution to South African nation-building will be over.

\section{Notes}

1

The authors are grateful to the IIE Fulbright program for supporting Karen Farquharson, who was a Fulbright Fellow to South Africa during 1995-1996, and to the University of Cape Town Sociology Department, which hosted Karen Farquharson in 1995-96. The authors also thank Sally Young for her work in collecting data used in this paper.

2

Data for the 1995 World Cup were collected by hand. For 1999 data were accessed from the Independent Newspaper website, http://www.iol.co.za (which contains data post-1996). On line data was collected in October and November 2001. Whenever possible, references to newspapers include the relevant page numbers. However, worldwide web editions of such material do not normally include a page number. Therefore, the absence of page numbers in material referenced in the text indicates that the source was consulted over the worldwide web.

Karen Farquharson is Lecturer in Sociology at Swinburne University of Technology. She is also Honorary Senior Fellow at the Department of Political Science at The University of Melbourne, and holds a PhD in Sociology from Harvard University. Her research interests include racial and ethnic relations, and health and tobacco control policy. Her email address is Kfarquharson@swin.edu.au

Timothy Marjoribanks is T.R. Ashworth Senior Lecturer in Sociology at The University of Melbourne, and holds a PhD in Sociology from Harvard University. His research interests include media-sport relations, and workplace relations in the media, sport and health industries. His email address is tkmarj@unimelb.edu.au 


\section{References}

Abrahams, David and Eric Ntabazalila. 1999. 'Include Players of Colour-Spectators', Cape Times www.iol.ca.za (1999-08-10).

Adam, Kanya. 1997. 'The Politics of Redress: South African Style Affirmative Action', The Journal of Modern African Studies 35(2): 231-49.

Anderson, Benedict. 1991. Imagined Communities: Reflections on the Origins and Spread of Nationalism, $2^{\text {nd }}$ edn. London: Verso.

Anthias, Floya and Yuval-Davis, Nira. 1992. Racialized Boundaries: Race, Nation, Gender, Colour and Class and the Anti-Racist Struggle. London: Routledge.

Asmal, Kader, Asmal, Louise and Suresh Roberts, Ronald. 1997. Reconciliation Through Truth: A Reckoning of Apartheid's Criminal Governance, $2^{\text {nd }}$ edn-with afterword. Cape Town: David Philip Publishers.

Blain, Neil, Boyle, Raymond and O’Donnell, Hugh. 1993. Sport and National Identity in the European Media. Leicester: Leicester University Press.

Booth, Douglas. 1996. 'Mandela and Amabokoboko: the Political and Linguistic Nationalisation of South Africa?', The Journal of Modern African Studies 34(3): 459

77. 1998. The Race Game: Sport and Politics in South Africa. London: Frank Cass. Cape Times.

1995a. ‘A Rugby Triumph for National Unity: editorial’, Cape Times 26 June: 8. 1995b. 'SA United in

Triumph', Cape Times 26 June: 3. 1995c. 'Bok Emblem Gains Extra Time', Cape Times 27 June: 1.

1995d. 'Mandela Praises Rugby for its Nation-Building', Cape Times 28 June: 3. 1996. 'To Bok or not to Bok:

editorial', Cape Times 11 March: 8. Christopher, A.J. 2001. The Atlas of Changing South Africa, $2^{\text {nd }}$ edition. London:

Routledge. Cridland, Elizabeth. 1996. 'Springbok the Victim of Dreary Politics-letter', Cape Times 27

March: 4. Croucher, Sheila. 1998. 'South Africa's Illegal Aliens: Constructing National Boundaries in a

Post-Apartheid State', Ethnic and Racial Studies 21(4): 639-60.

Davies, Alun. 1996. 'Letter', Cape Times 12 March: 6.

Del Carme, Liam. 1999. 'Bok Rugby has an Identity Crisis', The Sunday Independent

www.iol.ca.za (1999-12-05)

Dubow, Saul. 1995. Scientific Racism in Modern South Africa. Cambridge: Cambridge University Press.

Du Preez, Max. 1999. 'No Normal Sport in Abnormal Society', Cape Argus www.iol.co.za (1999-06-30).

Farquharson, Karen. 1999. 'Racialized Media Discourse in the "New” South Africa: the Makgoba Controversy', Research in Politics and Society 6: 175-94.

Frederickson, George M. 1995. Black Liberation: A Comparative History of Black Ideologies in the United States and South Africa. New York: Oxford University Press. Frederikse, Julie. 1990. The Unbreakable Thread: Non-Racialism in South Africa.

Bloomington, IN: Indiana University Press. Garrett, Peter and Bell, Allan. 1998. 'Media and Discourse: A Critical Overview'. Pp. 1-20 in Bell, Allan and Garrett, Peter (eds.), Approaches to Media Discourses. Oxford: Blackwell.

Glasspool, Barry. 1999. 'Mallett Names his World Cup Warriors', The Star www.iol.ca.za (1999-08-29).

Goldberg, David Theo. 1993. Racist Culture: Philosophy and the Politics of Meaning. Cambridge, MA: Blackwell.

Goodman, David. 1999. Fault Lines: Journeys into the New South Africa. Berkeley, CA: University of California Press.

Granger, Dale. 1997. ‘No “Rainbow” yet in Rugby’, Cape Times www.iol.co.za (1997-07-05). 
Greenaway, Mike. 1999a. 'The Way Forward for the Boks', Cape Times www.iol.co.za (199911-08).

. 1999b. ‘Why Sarfu can set Race Quotas', Daily News www.iol.co.za (1999-06-23)

Greenfeld, Liah. 1992. Nationalism. Five Roads to Modernity. Cambridge, MA: Harvard University Press.

Greenstein, Ran. 1993. 'Racial Formation: Towards a Comparative Study of Collective Identities in South Africa and the United States', Social Dynamics 19(2): 1-29.

Grundlingh, Albert, Odendaal, Andre and Spies, Burridge. 1995. Beyond the Tryline: Rugby and South African Society. Johannesburg: Ravan Press.

Hobsbawm, E.J. 1990 Nations and Nationalism since 1780: Programme, Myth, Reality. Cambridge: Cambridge University Press.

Independent On-Line. 2001. www.iol.co.za

Jacobs, Sean. 1999. 'Tensions of a Free Press: South Africa After Apartheid', The Joan Shorenstein Center on the Press, Politics and Public Policy Research Paper R-22, John F. Kennedy School of Government, Harvard University.

Jarvie, Grant. 1985. Class, Race and Sport in South Africa's Political Economy. London: Routledge and Kegan Paul. (ed). 1991 Sport, Racism and Ethnicity. London: Falmer Press.

Jarvie, Grant and Walker, Graham (eds). 1994. Scottish Sport in the Making of the Nation: Ninety Minute Patriots? Leicester: Leicester University Press.

Keech, Marc and Houlihan, Barrie. 1999. 'Sport and the End of Apartheid', The Round Table 34(9): 109-21.

Magubane, Bernard Makhosezwe. 1996. The Making of a Racist State: British Imperialism and the Union of South Africa, 1875-1910. Trenton, NJ: Africa World Press.

Marx, Anthony W. 1997. 'Apartheid's End: South Africa's Transition from Racial Domination', Ethnic and Racial Studies 20(3): 474-96.

1998. Making Race and Nation: A Comparison of the United States, South Africa, and Brazil. Cambridge: Cambridge University Press.

Miller, David. 1995. 'Mandela's Touch of Genius', Cape Times 27 June: 6.

Nattrass, Nicoli and Seekings, Jeremy. 2001. 'Democracy and Distribution in Highly Unequal Economies: the Case of South Africa', The Journal of Modern African Studies 39(3): 470-97.

Nauright, John. 1997. Sport, Culture and Identities in South Africa. London: Leicester University Press.

Ntabazalila, Eric. 1999. “Mallett Stirs up Storm', The Star www.iol.co.za (1999-06-23).

Omi, Michael and Winant, Howard. 1994. Racial Formation in the United States: From the 1960 to the 1990 s, $2^{\text {nd }}$ edn. New York: Routledge.

Philander, E. 1996. 'Teleletter', Cape Times 11 March: 8.

Pope, Steven W. 1993. 'Negotiating the "Folk Highway" of the Nation: Sport, Public Culture and American Identity, 1870-1940', Journal of Social History 27(2): 327-40.

Pretorius, Charmaine. 1999. 'Mbeki encore for SA's sporting champs', Independent OnLine www.iol.ca.za (1999-1106)

Rantao, Jovial. 1998. 'Tshwete Warns of Anti-Rugby Backlash against Rugby', The Star www.iol.co.za (1998-02-13).

Rees, Roger C. 1996. 'Race and Sport in Global Perspective: Lessons from Post-Apartheid South Africa', Journal of Sport and Social Issues 20(1): 22-7.

Rich, Gavin. 1999a. 'Rain and race-row hangs over Wales test', Saturday Star www.iol.ca.za (1999-06-25). 1999b. 'Rugby Revolution could Spell Disaster', The Sunday Independent www.iol.co.za (1999-08-14). 1999c. 'Bob's Giant Stride to Bring Back Cup', Cape Argus www.iol.co.za (1999-08

24). 
. 1999d. 'Too Small, or Just Too Black', Cape Argus www .iol.ca.za (1999-07-14)

Roberts, Cheryl (ed). 1989. Sport and Transformation, Contemporary Debates on South

African Sport. Cape Town: Township Publishing Co-operative. Saturday Star. 1999. 'SA Fans Join Boks in Spirit and Song', Saturday Star www.iol.co.za

(1999-10-01).

Schudson, Michael. 1995. The Power of News. Cambridge, MA: Harvard University Press.

Seidman, Gay. 1999. 'Is South Africa Different? Sociological Comparisons and Theoretical

Contributions from the Land of Apartheid', Annual Review of Sociology 25: 419-40.

Steenveld, Lynette and Strelitz, Larry. 1998. 'The 1995 Rugby World Cup and the Politics of Nation-Building in South Africa', Media, Culture and Society 20(4): 609-29.

Street, John. 2001. Mass Media, Politics and Democracy. Hampshire, UK: Palgrave.

Van Dijk, Teun A (ed.). 1997. Discourse as Social Interaction. Discourse Studies: A Multidisciplinary Introduction, Volume 2. London: Sage.

Williams, Paul and Taylor, Ian. 2000. 'Neoliberalism and the Political Economy of the "New" South Africa', New Political Economy 5(1): 21-40. 


\section{University Library}

\section{- M M I N E R VA A gateway to Melbourne's research publications}

Minerva Access is the Institutional Repository of The University of Melbourne

Author/s:

FARQUHARSON, KAREN;Marjoribanks, Timothy

Title:

Transforming the Springboks? Re-imagining the South African nation through sport

Date:

2003

Citation:

Farquharson, K., \& Marjoribanks, T. (2003). Transforming the Springboks? Re-imagining the South African nation through sport. Social Dynamics, 29(1), 27-48.

Publication Status:

Published

Persistent Link:

http://hdl.handle.net/11343/34425 